軽金属 第 54 巻第 9 号 (2004), 388-393

\title{
ロータス型ポーラスマグネシウムおよび その合金の作製と機械的性質
}

\author{
Journal of Japan Institute of Light Metals, Vol. 54, No. 9 (2004), pp. 388-393

\section{Fabrication and mechanical properties of lotus-type porous magnesium and its alloys}

池田 輝之* · 星山 英男 **. 中嶋 英雄 $*$

Teruyuki IKEDA*, Hideo HOSHIYAMA** and Hideo NAKAJIMA*

\section{1.はじめに}

最近，マグネシウムやその合金は軽量材料として種々の家 電製品, コンピュータや携帯電話の筐体, 自動車部材などに 使用されつつあり, 益々その素材としての重要性が認識され つつある。マグネシウムを多孔質化することができれば，さ らなる軽量化により超軽量金属材料となりうるとともに, 孔 の存在による大きな表面積などを利用した新機能材料として あ期待できる。

従来の多くの多孔質金属は, 発泡金属や焼結金属に代表さ れるように球状ポアを有するが, 本稿で紹介するのは, 一方 向の微細孔を有するポーラス金属であり, 球状ポアを有する ポーラス金属と比較して際だった特徽を有している。一方向 凝固によって長尺ポアのポーラス金属を作製する試みは, Svensson ¿ Fredriksson ${ }^{1)}$, Knacke $ら^{2)}$, Boiko $ら^{3)}$, 中嶋 ${ }^{4) ~ 8) ~}$ によって行われてきた。我々のグループでは，一方向凝固を 利用した新しいポーラス金属の製造方法を開発している。

本稿では，まず一方向に揃った多数の微細孔を有するポー ラス金属の製造方法を解説し，その後，ポーラスマグネシウ ムおよびマグネシウム合金の作製の現状とポーラスマグネシ ウムの機械的性質を紹介する。

\section{2. ロータス型ポーラス金属の作製方法}

我々のグループでは，金属を溶融状態から一方向凝固さ せ，その際に過飽和ガス原子を金属内に一方向にポアとして 放出させることによりポーラス金属を作製している。すなわ ち, 溶融金属におけるガス原子の溶解度が大きく, その固体 金属中での固溶度が小さい場合, 凝固時に固溶しきれない力゙ ス原子がポアを形成することを利用している(2)8)。図 1 に, 例として水素標準気圧中のマグネシウムの水素溶解度を示 $す^{9)}$ 。水素溶解度は温度上昇とともに増加しているが, 融点 では溶解度の増加が不連続である。マグネシウム以外にも， ニッケル，鉄，銅などの金属およびそれらの合金において，
融点で水素溶解度が不連続に増加する。このことは，凝固の 際に多量の水素がガスとして放出されることを意味しており, ポアの生成原因となる。このような水素溶解度差を利用して, さらに図 2 のように一方向凝固を行わせることによりポアに 方向性をむたせることができる。このようにして，一方向に 揃った長い微細孔を有するポーラスマグネシウムを作製する ことができる。

図 3 のように，ハース (鋳型) に水冷部を設けて流し込ん だ溶融金属を下方から，あるいは側面から方向性凝固させる とポアの成長方向は，それぞれ下から上へ向かう一方向性多 芯状構造に, あるいは円周から中心に向かって放射状構造に なる。特に（a）のように下から冷却凝固させると蓮根（lotus root）に似た孔の形状をむつポーラス金属が得られるので, 我々はそのような金属をロータス型ポーラス金属と呼んでい る。本製造方法によるポーラス金属は, 方向, ポアサイズ, ポロシティ（空隙率）を制御することができることや，強度 の極端な劣化を生じないことなど, 従来の発泡金属, 焼結金 属などとは異なる特徵を有している。ポア形態制御のための パラメータには, 溶融温度, 凝固冷却速度, 溶解時の雲囲気

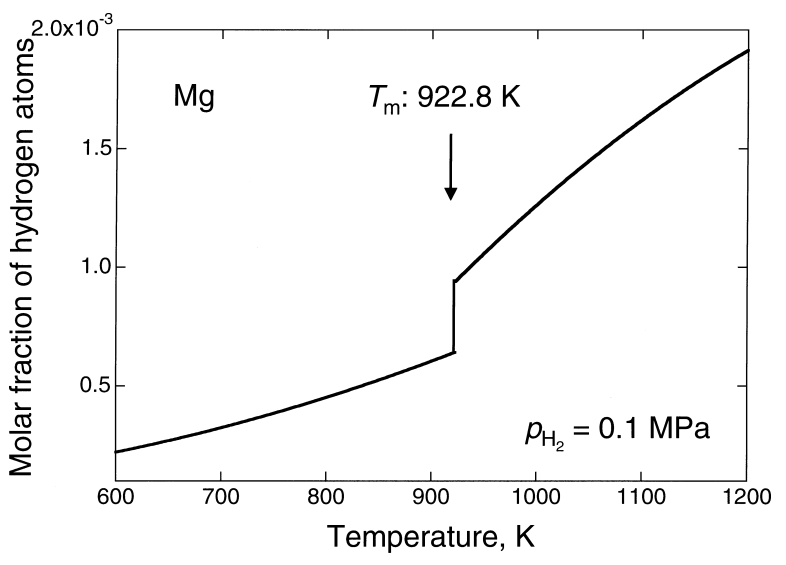

図 1 マグネシウムにおける水素溶解度の温度依存性

*大阪大学産業科学研究所 ( (8-1 Mihogaoka, Ibaraki-shi, Osaka 567-0047).

***大阪大学大学院工学研究科マテリアル科学専攻 (吹田市) [現在：(森)本田技術研究所]。Department of Materials Science and Engineering, Osaka University (Suita-shi Osaka) [Present: Honda R\&D Co., Ltd.].

受理日：平成 16 年 5 月 20 日 


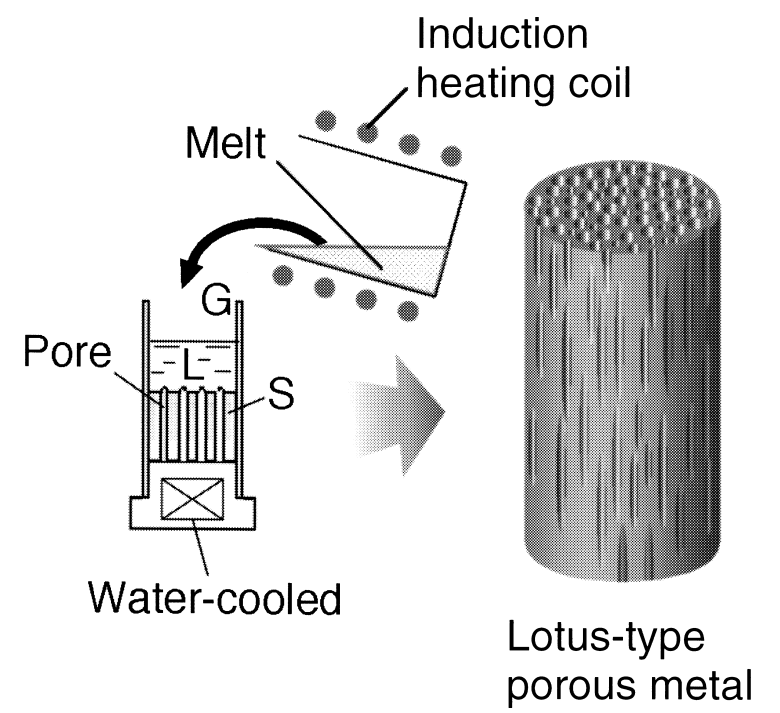

図 2 ロータス型ポーラス金属の作製原理
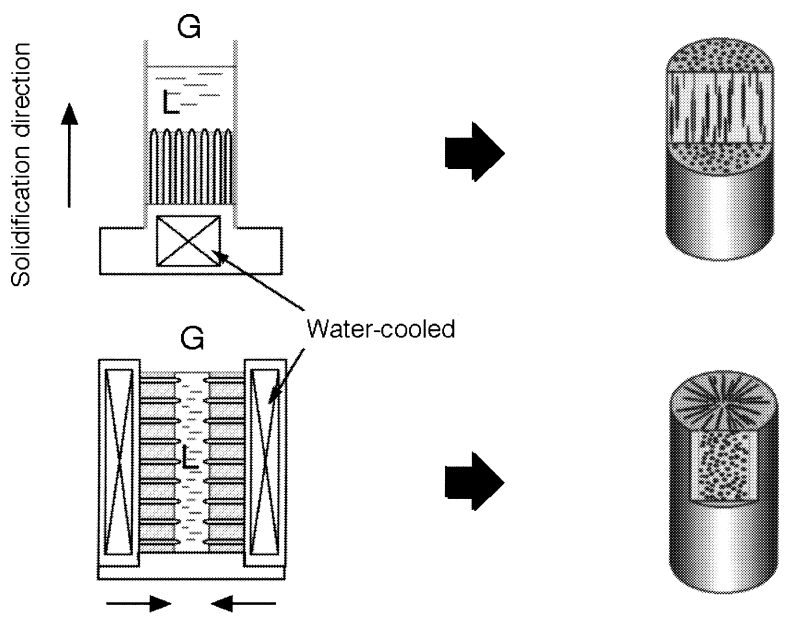

Solidification direction

図 3 ロータス型ポーラス金属のポアの成長方向

ガス圧力, 不活性ガスとの混合体積比, 凝固時のガス圧力な よ゙が挙げられる10) 13)。

これまでに，水素雾囲気下で銅14) や鉄15)，ニッケル16)，ス テンレス鋼17) など，酸素䨌囲気下で銀18) や金，安全性の高

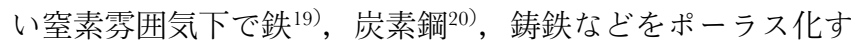
ることに成功している。なお，マグネシウム，マグネシウム 合金のポーラス化については，一部を文献 21 や文献 22 でも 報告しているので，参照して頂きたい。最近では，連続帯溶 融法により丸棒状ポーラス金属を作製することも可能となっ た ${ }^{23)}$ 。さらに, 連続鋳造方式を採用すれば, 長尺の棒状, 板 状のポーラス金属む作製できると考えられる。

\section{3. ロータス型ポーラスマグネシウムおよびマグネシ ウム合金の作製}

\section{1 実験方法}

純度 99.9\% のマグネシウムあるいはマグネシウム合金 AZ31B，AZ91D あるいは AZ91D をマグネシウムで 3 倍に希 釈した合金（以下（1/3）AZ91D と略す）約 $1 \mathrm{~kg}$ をグラファ イトるつぼ中に入れ，さまざまな圧力（0.15２.52 MPa）の
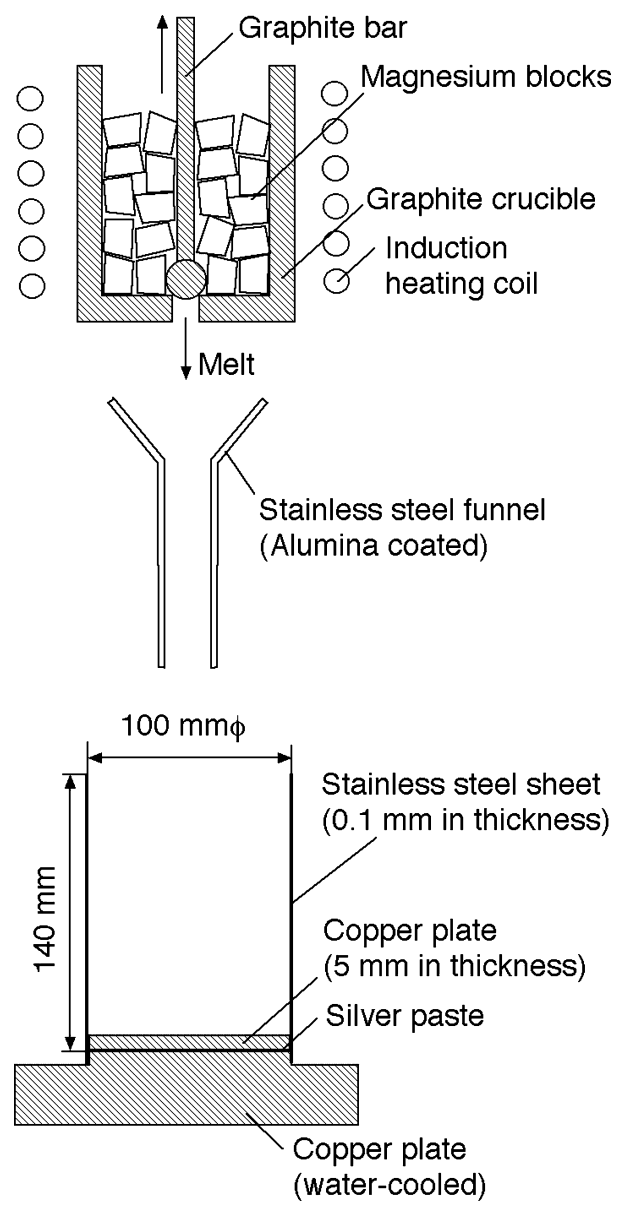

図4ロータス型ポーラスマグネシウム作製のための溶 解るつぼ，漏斗抢よび一方向凝固させるための鋳 型

水素雾囲気の下で高周波加熱を行い溶解させた。図 4 に示す ように, グラファイトるつぼには, 底部に直径 $20 \mathrm{~mm}$ の穴が あり，溶湯が漏れないように先端が球型のグラファイト製の 棒で栓をしている。溶解後, 水素を十分に溶湯中に溶解させ るため，溶湯を $1.2 \mathrm{ks}$ の間各々の合金の融点よりも $130 \mathrm{~K}$ 高 い温度に保持した。その後, グラファイト製の栓を上昇させ, アルミナセメントで被覆したステンレス鋼製の漏斗を介して 溶湯を下部の鋳型中に流し込み一方向凝固させた。鋳型は直 径 $100 \mathrm{~mm}$, 高さ $140 \mathrm{~mm}$ の円柱状とした。鋳型底面には，水 冷した銅板の上に銀ペーストを用いて厚さ $5 \mathrm{~mm}$, 直径 $100 \mathrm{~mm}$ の円板を貼付けた。側面は, 厚さ $0.1 \mathrm{~mm}$ のステンレ ス鋼板を円筒状に成型したものであり，これを底面の銅円板 に巻付けて固定している。厚さ $0.1 \mathrm{~mm}$ の薄板を用いること により，鋳型側面の熱容量を小さくし，側面への熱の逃げを 抑え, 凝固が底面から上方へ一方向に起こるようにしている。 なお，ノンポーラス試料を作製する際には，溶解および鋳込 み時の雾囲気を $0.3 \mathrm{MPa}$ の圧力のアルゴンガスとした。

ワイヤーカット放電加工機を用いて，作製された鋳塊を凝 固方向に垂直あるいは平行に切断し，断面を観察した。ポア の伸び方向に垂直な断面の写真を計算機上に取込み, 画像解 析ソフトウェア（三谷商事株式会社製 Macscope ver. 2.54）を 用いて解析し，ポロシティおよび平均ポア直径を求めた。

\section{2 結果と考察}

図 5 に, $0.3 \mathrm{MPa}$ の水素雾囲気下で作製したロータス型 

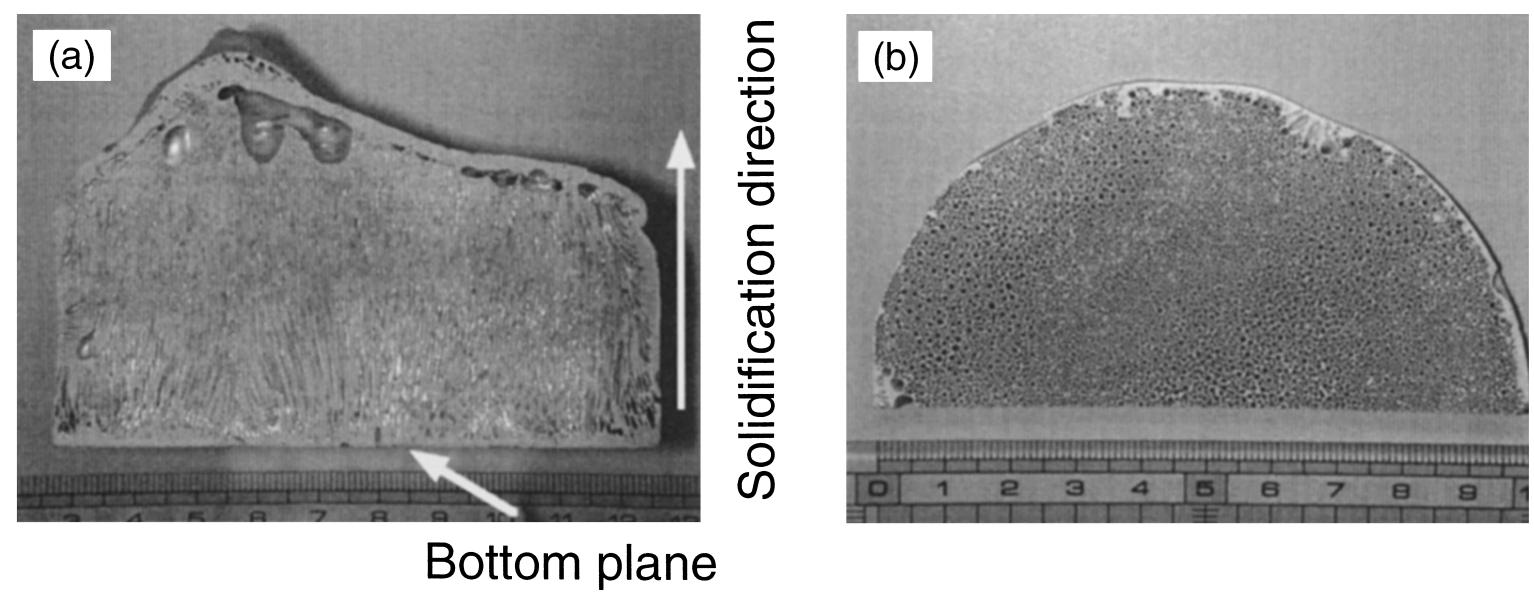

図 5 水素 $0.3 \mathrm{MPa}$ の雾囲気下で作製したロータス型ポーラスマグネシウムの凝固方向に平行な断面（a）と垂直な断 面 (b)

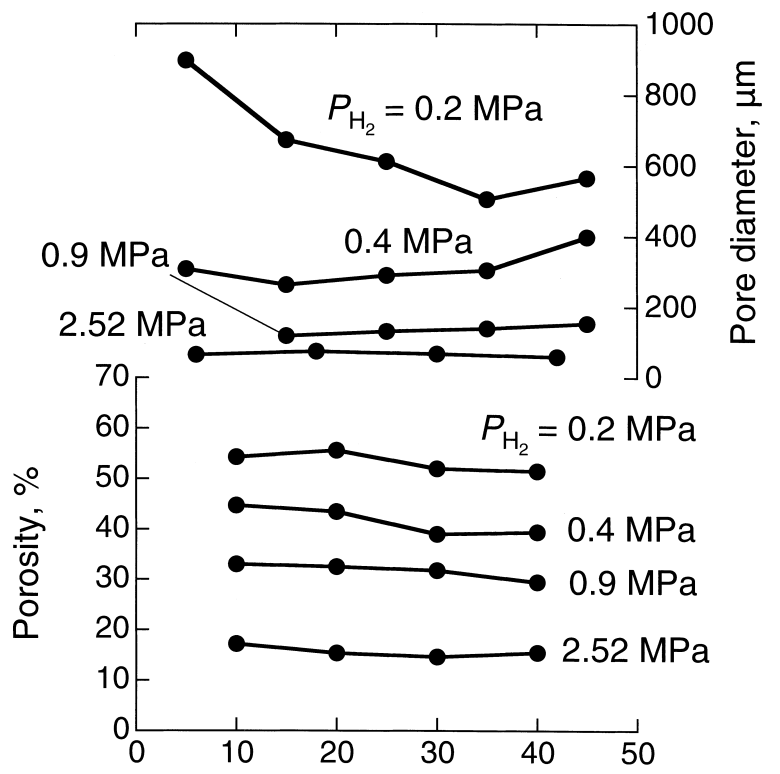

Distance from bottom plane, $\mathrm{mm}$

図 6 さまざまな圧力の水素雾囲気下で作製したロー夕 ス型ポーラスマグネシウムのポロシティおよび平 均ポア直径と冷却面からの距離との関係

ポーラスマグネシウムの鋳塊中の凝固方向に垂直な面と平行 な面を示す。凝固方向に平行に伸びた円柱状のポアが，多数 分散している。

ポロシティ（ポアの体積分率）は, 水素ガスの圧力を变化 させることにより制御が可能である。図 6 は, 様々な水素ガ ス圧力下で作製したロータス型ポーラスマグネシウムのポロ シティおよびポア径を冷却面からの距離に対してプロットし たものである。ポロシティおよびポア径は水素ガスの圧力が 大きいほど小さくなる傾向が見られた。溶融金属中に溶解す る水素のモル数は, Sieverts 則により水素圧力の平方根に比 例することが知られている。一方, ポア内のガスの圧力は雾 囲気の圧力とほぼ釣合わねばならないため，ポアの体積は Boyle の法則により雾囲気の圧力と反比例の関係となると考 えられる。ポロシティが水素の圧力の増加に伴い減少するの は，圧力の増加によるポア体積の減少の効果が支配的である

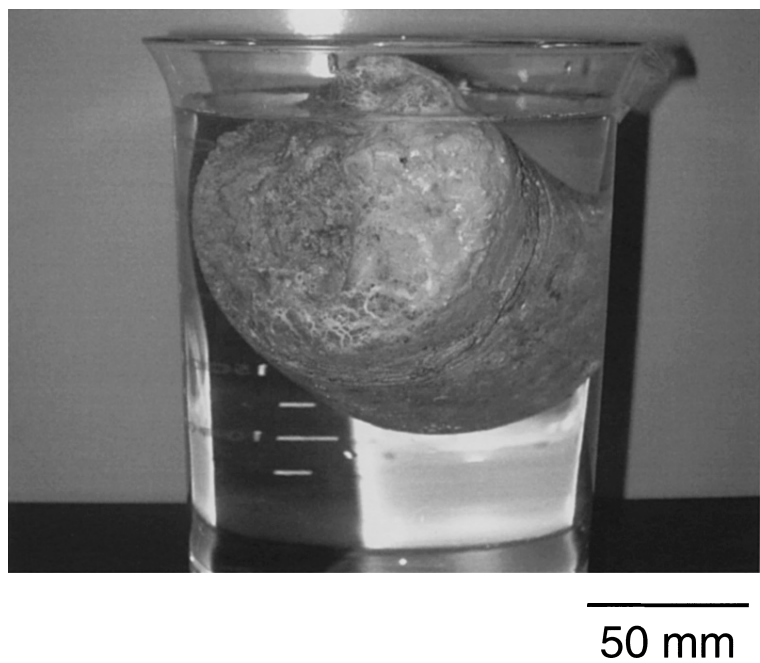

図 7 水中に浮かぶロータス型ポーラスマグネシウムの 鋳塊。水素 $0.2 \mathrm{MPa}$ の雾囲気下で作製

ことによると推察される。また，どの圧力においても，ポロ シティは冷却面からの距離によらずほぼ一定である。水素ガ ス $0.2 \mathrm{MPa}$ の雾囲気下で作製した場合はポロシティは $50 \%$ を 越え, 密度は $0.8 \mathrm{~g} / \mathrm{cm}^{3}$ 程度となり, 図 7 のように水に浮か ぶ鋳塊が得られた。

次に，水素圧 $0.4 \mathrm{MPa}$ の下で作製した 3 種類のポーラスマ グネシウム合金の凝固方向に平行な断面の写真を図 8 に示す。 （1/3）AZ91DとAZ31Bでは冷却面に近い領域でポアが一方 向に伸びているのが観察される。AZ91Dにおいては, 観察さ れるのはほとんど球状のポアである。（1/3）AZ91D とAZ31B を比べると, 添加元素濃度の少ない（1/3）AZ91Dの方が, よりポアが伸びている。また，図 9 には，鋳塊の底面から高 さ約 $10 \mathrm{~mm}$ の凝固方向に垂直な断面の写真を示す。同写真 からもわかるように，合金元素 $(\mathrm{Al}, \mathrm{Zn}, \mathrm{Mn})$ の濃度が高く なるにつれ，ポアの数が減少している。ポロシティも，39, 39，32\% と減少する傾向にある。マグネシウム中に $\mathrm{Al}$ や $\mathrm{Zn}$ 等の元素を添加すると, 同じ温度で比較すると水素溶解度が

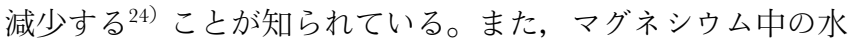
素溶解度は, 温度が低下すると減少する ${ }^{9)}$ 。いずれにしても, 合金元素濃度が高くなり融点が低下すると融点における水素 

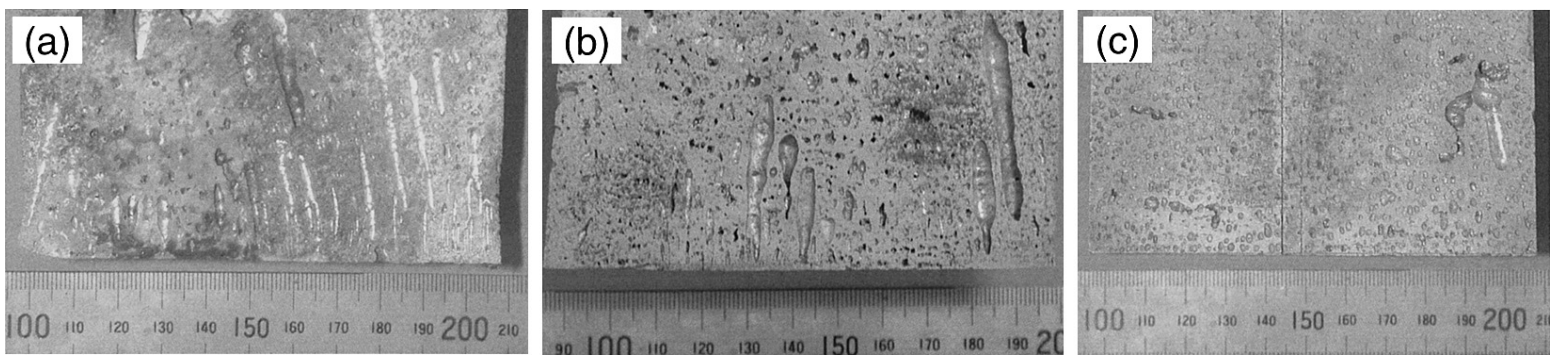

図 8 水素 $0.4 \mathrm{MPa}$ の雾囲気下で作製したポーラスマグネシウム合金（1/3）AZ91D（a), AZ31B（b）および AZ91D (c) の凝固方向に平行な断面
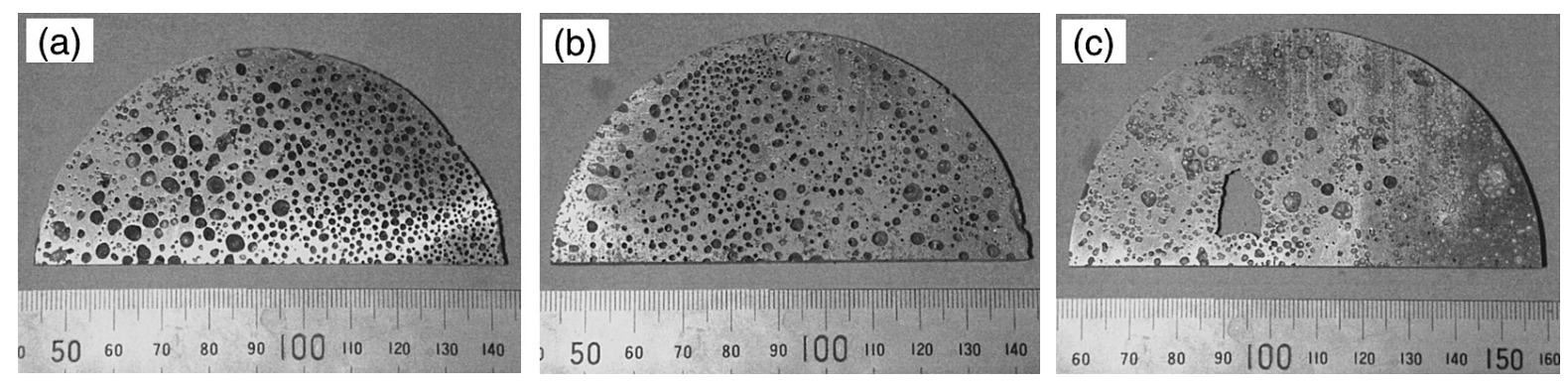

図 9 水素 $0.4 \mathrm{MPa}$ の雾囲気下で作製したポーラスマグネシウム合金（1/3）AZ91D（a）, AZ31B（b）および AZ91D （c）の冷却面から $10 \mathrm{~mm}$ の高さにおける凝固方向に垂直な断面

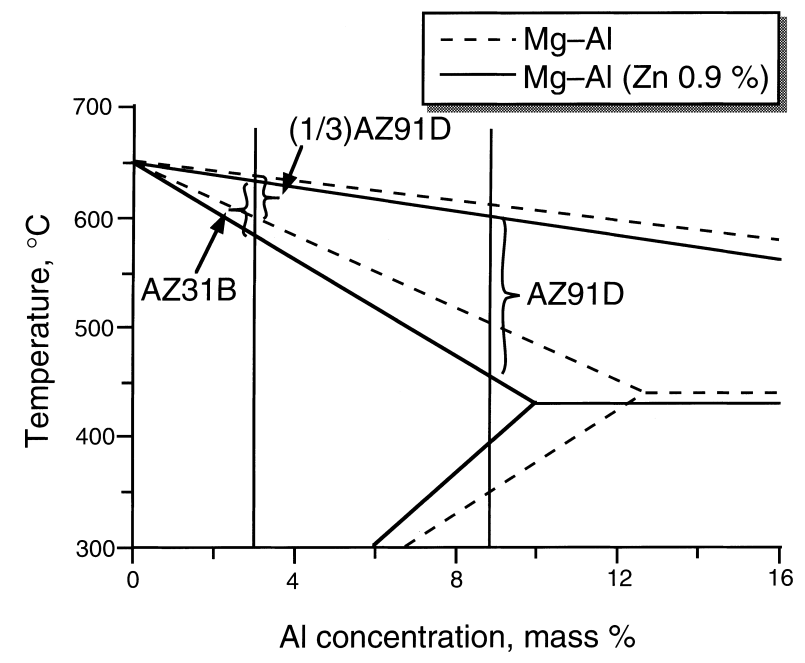

図 10 マグネシウムが高濃度の領域の $\mathrm{Mg}-\mathrm{Al}$ 系平衡状 態図

溶解度は減少すると考えられる。このことより，マグネシウ ム合金中で合金元素 $(\mathrm{Al}, \mathrm{Zn}, \mathrm{Mn})$ の濃度が高くなるとポロ シティが減少するのは, 水素溶解度の減少によりポアの形成 に関わる水素量が減少するためと考えられる。

図 8 より（1/3）AZ91DとAZ31B は高さ約 $10 \mathrm{~mm}$ では, 多くのポアが一方向に伸びているが, 高さ約 $60 \mathrm{~mm}$ では一方 向に伸びていないポアが大半を占めている。また，AZ91Dに おいては，鋳塊の全体にわたりポアは一方向に伸びていない。 通常, 冷却面に近い領域の冷却速度は大きいことから, ポア が一方向に伸びている領域では，冷却速度が大きいと考えら れる。定常状態では, 冷却速度は温度勾配と凝固速度の積で 表わされるが，この結果からのみでは，ポアが一方向に伸び る条件として, 凝固速度が大きいことが影響しているのか,

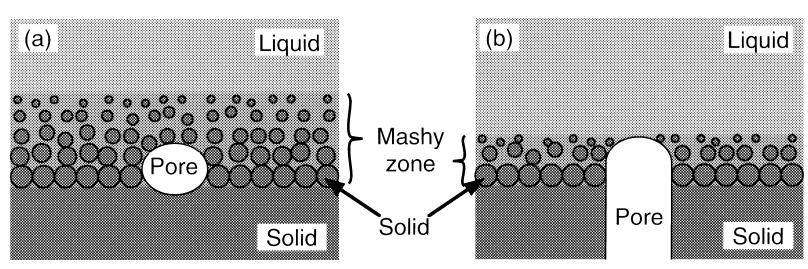

図 11 ポアの成長に対する固液二相領域の影響。固液二 相領域が広い場合（a）と狭い場合（b）

温度勾配が大きいことが影響しているのか，あるいはその両 方が影響するのかを断定することはできない。

そこで以下に，条件により円柱状あるいは球状のポアが生 成する原因を考察してみる。図 10 に $\mathrm{Mg}-\mathrm{Al}$ （Zn 0.9\% 添加） 系状態困 ${ }^{25)}$ を示す。液相線と固相線の間隔 $\Delta T$ は, $\mathrm{Mg}-3 \mathrm{Al}$ ((1/3) AZ91Dに近い) が $43.5 \mathrm{~K}, \mathrm{AZ31B}$ が $52.5 \mathrm{~K}, \mathrm{AZ91D}$ が $150 \mathrm{~K}$ と，合金元素濃度が高いほど大きい。それぞれの合金 の熱伝導率は, AZ31B が $75 \mathrm{~W} /(\mathrm{m} \cdot \mathrm{K})^{26)}$, AZ91D が $75 \mathrm{~W} /$ $(\mathrm{m} \cdot \mathrm{K})^{26)}$ と変わらない。また $(1 / 3) \mathrm{AZ} 91 \mathrm{D}$ と AZ31B の組成 はあまり変わらないので, 熱伝導率に関しては, 3 つの合金 でほぼ同じであると考えられる。よってすべての試料で凝固 時の温度勾配はあまり違いはないと考えられる。つまり, 凝 固時の固液共存域の幅は, ほぼ $\Delta T$ のみに依存すると考えら れる。したがって, 合金元素濃度が高いほど, 凝固時の固液 共存域の幅は広いと考えられる。

次に, 固液共存域の温度幅が, ポアの伸びに対し, どのよ うに影響しうるかを考察してみる。温度の低下に伴い, 固液 共存状態を経て凝固する場合, 固液共存域中において, 固相 率の増加に伴い, 固相から排出された水素ガスが, 液相中に 濃化し, ポアが生成される。固液共存域が広い場合を図 11 の（a）に模式的に示すように，ポアが生成してもすでに前 方に固相が晶出しており, ポアが固相に阻まれ, 成長して伸 


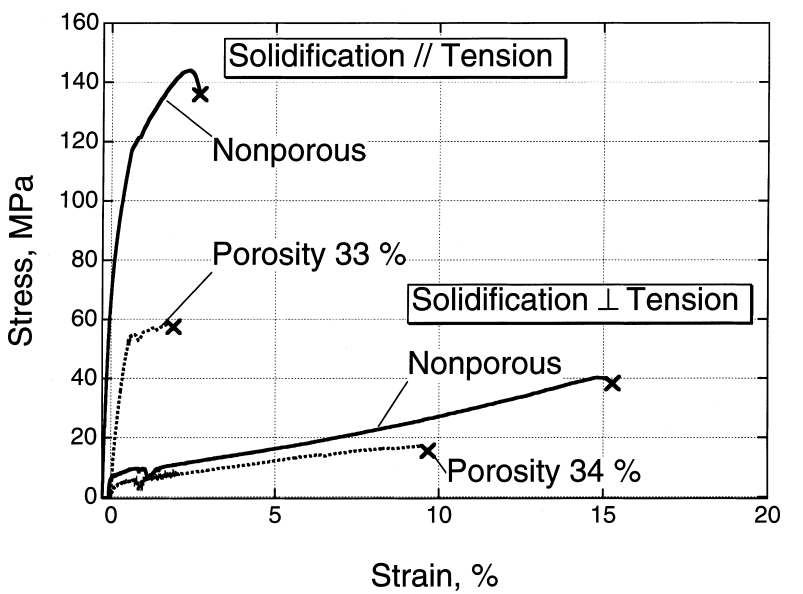

図 12 ノンポーラスおよびポーラスマグネシウムの凝固 方向に平行执よび垂直な方向での引張試験で得ら れた応力一歪み曲線

びるのが困難であると考えられる。一方，（b）に示すように 固液共存域が短いと，ポアの前方にポアの成長を妨げる固相 が少なく，成長することが可能であると考えられる。した がって，固液共存域が短い方がポアは一方向に伸びやすいと 考えられる。固液共存域の温度幅が小さい合金ほど，長いポ アが生成するのはそのためであると考えられる。そうすると， (1/3) AZ91D とAZ31Bが冷却面近傍でポアの伸びが見られ るのは，その領域の凝固の際に温度勾配が大きいことにより やはり固液共存域が短いためと考えられる。これらのことか ら，固液共存域の温度幅が大きい合金でも温度勾配を大きく すれば，固液共存域は狭くなり，ポアが伸びる可能性がある と予想できる。

\section{4. ロータス型ポーラスマグネシウムの引張試験}

\section{1 実験方法}

アルゴン $0.3 \mathrm{MPa}$ の雾囲気で作製したノンポーラスマグネ シウムと水素 $0.9 \mathrm{MPa}$ の雾囲気で作製したポーラスマグネシ ウムから，ワイヤーカット放電加工機を用いて，凝固方向に 垂直あるいは平行の 2 種類の引張試験片を切出した。試験 は，引張試験機（Instron 社製 Model 4482）を用いて室温に て行った。クロスヘッド速度は $0.5 \mathrm{~mm} / \mathrm{min}$ とした。

また，鋳塊中の結晶成長方位を調べるために，粉末 X 線回 折装置（理学電機株式会社製 MJ200KE 型）を用いて凝固方 向に垂直な面の反射を測定した。

\section{2 結果と考察}

図 12 に測定された応力一歪み曲線を示す。ノンポーラス 試料において，凝固方向に垂直な荷重と平行な荷重の結果を 比較すると，平行な場合には引張強さが著しく大きく，伸び が著しく小さい。一方向凝固で得られた鋳塊は凝固方向に伸 びた柱状晶からなるが，引張変形挙動の異方性は，そのよう な結晶の優先成長方位を反映しているあのと考えられる。図 13 に，X線回折実験より得られた反射ピークプロファイルを 示す。アルゴンガス $0.3 \mathrm{MPa}$ の雾囲気下で作製したノンポー ラス鋳塊では，優先成長方位は $<0002>$ あるいは <1120>で ある。マグネシウムにおいては，室温で活動するすべり系は (0002) $<112 \overline{2} 0>$ のみであると報告されている27)。図 14 に示す ように，成長方位が $<11 \overline{2} 0>$ の結晶粒は，（0002）の法線が

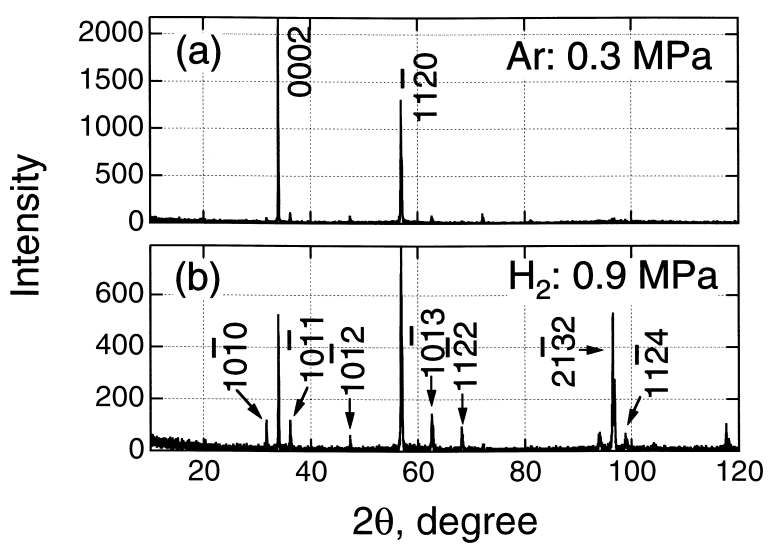

図 13 ノンポーラス（a）抢よびポーラスマグネシウム （b）の凝固方向に垂直な断面で得られたX 線回 折プロファイル
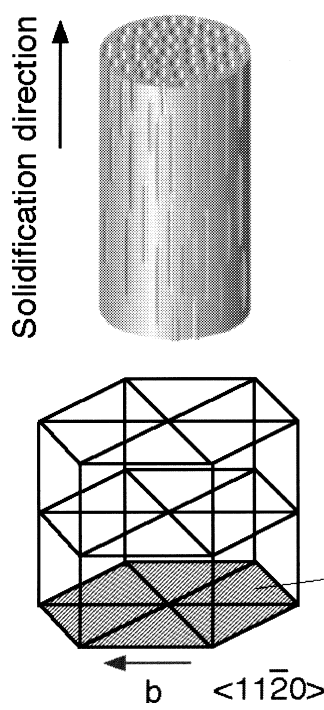

$\{11 \overline{2} 0\}$

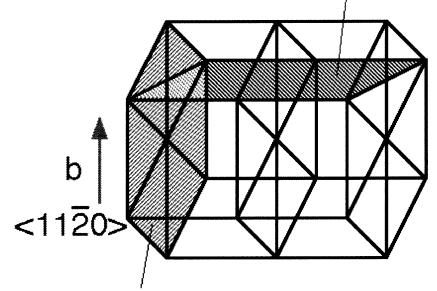

$\{0002\}$

$\{0002\}$

図 14 ノンポーラスおよびポーラスマグネシウムの凝固 方向と優先成長方位，すべり面の関係

凝固方向に垂直なランダムな方向であるため, 凝固方向に垂 直な引張に対して，（0002）<1120>のすべり系が活動する。 一方, 凝固方向に平行な引張に対しては，優先成長方位が <0002> あるいは<1120>のどちらの結晶粒にとってもすべり 系 $(0002)<11 \overline{2} 0>$ のシュミット因子が 0 に近い。これが，， ンポーラス試料で凝固方向に平行な引張の方が, 变形が起こ りにくい原因である。これに対し，ポーラス試料の応力一歪 み曲線では，それぞれの引張方向において応力值がノンポー ラス試料のそれに比べて減少しており，ノンポーラス試料に おける異方性と同じ異方性が見られる。このことは，図 13 からわかるように，ポーラス試料においても，若干他の方位 の成長が見られるものの主な成長方位はノンポーラス試料と 変わらず $<0002>$ あるいは $<11 \overline{2} 0>$ であることから理解でき る。このように，引張変形挙動についてはロータス型ポーラ スマグネシウムはノンポーラス試料と同様の異方性を有する。

\section{5. まとめ}

水素䨌囲気下での溶解後, 鋳造法により一方向凝固させる ことにより，凝固方向に伸びた多数のポアが分散したロー夕 
ス型ポーラスマグネシウムを作製することができた。ポロシ ティ, 平均ポア直径は, 水素ガスの圧力を变化させることに より変化させることができる。実験を行った条件下では，ポ

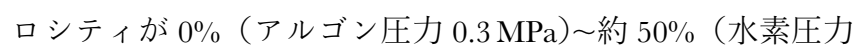
$0.2 \mathrm{MPa}$ ), 平均ポア直径が 60 (水素圧力 $2.52 \mathrm{MPa}$ ) $800 \mu \mathrm{m}$

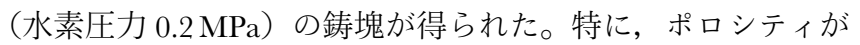
約 $50 \%$ のポーラスマグネシウムは密度が約 $0.87 \mathrm{~g} / \mathrm{cm}^{3}$ と非常 に軽量であり, 水に浮く。このように, 本方法によるポーラ ス化により, 実用軽量材料として注目されるマグネシウムを さらに軽量化することができた。

AZ31B，AZ91D といった実用合金も同様の方法でポーラス 化を試みたところ球状のポアが生成した。これは，合金では 凝固過程において固液二相領域で生成したポアの凝固方向へ の成長が周囲の固相により妨げられているためと考えられる。 したがって, 凝固時の温度勾配をより大きくすることにより 固液二相領域を狭くすれば，ポアが伸張する可能性がある。 このことは，マグネシウム合金に限らず，他の合金系でも当 てはまる場合があると考えられる。この知見をもとに，現在， 我々は凝固方向に伸張したポアが均一に生成したポーラスマ グネシウム合金を作製するための研究を継続している。今後 の展開が期待される。

\section{参考 文 献}

1) I. Svensson and H. S. Fredriksson: Proc. Int. Conf. organized by the Applied Metallurgy and Metals Tech. Group of TMS, U. of Warwick, (1980), 376.

2) O. Knacke, H. Probst and J. Wernekinck: Z. Metallkde, 70 (1979), 1.

3) L. V. Boiko, V. I. Shapovalov, E. A. Chernykh: Metallurgiya, 346 (1991), 78.

4) S. K. Hyun, Y. Shiota, K. Murakami and H. Nakajima: Proc. Int. Conf. on Solid-Solid Phase Transformations '99 (JIMIC-3), M. Koiwa, K. Otsuka and T. Miyazaki (Eds.), Japan Inst. Metals, Kyoto, 1999, p. 341.

5) S. K. Hyun, K. Murakami and H. Nakajima: Mater. Sci. Eng., A299 (2001), 241.
6) H. Nakajima, S. K. Hyun, K. Ohashi, K. Ota and K. Murakami: Colloids Surfaces A: Physicochem. Eng. Aspects, 179 (2001), 209.

7) S. K. Hyun, K. Murakami and H. Nakajima: Cellular Metals and Metal Foaming Technology, ed. J. Banhart, M. F. Ashby and N. A. Fleck, MIT Verlag (2001), 421.

8) H. Nakajima, S. K. Hyun and K. Murakami: Advanced Tech. Mater., 4 (2002), 13.

9) K. Zeng, T. Klassen, W. Oelerich and R. Bormann: Inter. J. Hydrogen Energy, 24 (1999), 989.

10）中嶋英雄：マテリアルインテグレーション，12（1999）， 37.

11）中嶋英雄：機能材料, 20 (2000), 27.

12）中嶋英雄：高温学会誌, 26（2000）, 95.

13）中嶋英雄：ふ元らむ，6（2001），701.

14) S. K. Hyun, K. Murakami and H.Nakajima: Mater. Sci. Eng., A299 (2001), 241.

15) S. K. Hyun and H. Nakajima: Proc. Int. Conf. on Designing of Interfacial Structures in Advanced Materials and their Joints, M. Naka (Ed.), High Temperature Society of Japan, Osaka (2002), 293.

16）山村 聡, 玄丞 均, 中嶋英雄 : 第 126 回日本金属学会概要, (2000), 413.

17) T. Ikeda, M. Tsukamoto and H. Nakajima: Mater. Trans., 43 (2002), 2678.

18）中畑拓治, 中嶋英雄：第 133 回日本金属学会概要, (2003), 380.

19) S. K. Hyun and H. Nakajima: Mater. Trans., 43 (2002), 526.

20）樫原一，米谷 周，小尾孝宏，玄丞 均，中嶋英雄：第 134 回日本金属学会概要, (2004), 134.

21）池田輝之, 中嶋英雄：鋳造工学， 74（2002）， 812.

22）星山英男, 池田輝之, 村上健児, 中嶋英雄：日本金属学会誌, 67 (2003), 714.

23) H. Nakajima, T. Ikeda and S. K. Hyun: Cellular Metals and Metal Foaming Technology, ed. J. Banhart and N. A. Fleck, MIT-Verlag, Berlin, (2003), 191.

24）渡辺哲男, 立原祥弘, 黄燕清, 小松龍造：軽金属, 25 （1976）, 167.

25）日本マグネシウム協会編：マグネシウム技術便覧，カロス出版， (2000), 90.

26）日本マグネシウム協会編：マグネシウム技術便覧，カロス出版， (2000), 58.

27）麻田 宏, 吉永日出男：日本金属学会誌，23（1959）, 67 . 